\title{
Authentic Cell-Specific and Developmentally Regulated Expression of Pro-Opiomelanocortin Genomic Fragments in Hypothalamic and Hindbrain Neurons of Transgenic Mice
}

\author{
Juan I. Young, ${ }^{1}$ Verónica Otero, ${ }^{1}$ Marcelo G. Cerdán, ${ }^{1}$ Tomás L. Falzone, ${ }^{1}$ E. Cheng Chan, ${ }^{2}$ Malcolm J. Low, ${ }^{2}$ \\ and Marcelo Rubinstein ${ }^{1,3}$ \\ 1/nstituto de Investigaciones en Ingeniería Genética y Biología Molecular, Universidad de Buenos Aires-Consejo Nacional \\ de Investigaciones Cientificas y Técnicas, 1428 Buenos Aires, Argentina, 2Vollum Institute, Oregon Health Sciences \\ University, Portland, Oregon 97201, and '3epartamento de Química Biológica, Facultad de Ciencias Exactas y Naturales, \\ Universidad de Buenos Aires, 1428 Buenos Aires, Argentina
}

\begin{abstract}
The pro-opiomelanocortin (POMC) gene is expressed in a subset of hypothalamic and hindbrain neurons and in pituitary melanotrophs and corticotrophs. POMC neurons release the potent opioid $\beta$-endorphin and several active melanocortins that control homeostasis and feeding behavior. POMC gene expression in the CNS is believed to be controlled by distinct cis-acting regulatory sequences. To analyze the transcriptional regulation of POMC in neuronal and endocrine cells, we produced transgenic mice carrying $\mathrm{POMC}^{*} 7^{*}$, a transgene containing the entire $6 \mathrm{~kb}$ of the POMC transcriptional unit together with $13 \mathrm{~kb}$ of $5^{\prime}$ flanking regions and $8 \mathrm{~kb}$ of $3^{\prime}$ flanking regions. POMC27* was tagged with a heterologous $30 \mathrm{bp}$ oligonucleotide in the third exon. In situ hybridization studies showed an accurate cell-specific pattern of expression of POMC27* in the arcuate nucleus and the pituitary. Hypothalamic mRNA-positive neurons colocalized entirely with $\beta$-endorphin immunoreactivity. No ectopic transgenic expression was detected in the brain.
\end{abstract}

Deletional analyses demonstrated that neuron-specific expression of POMC transgenes required distal 5' sequences localized upstream of the pituitary-responsive proximal cis-acting elements that were identified previously. POMC27* exhibited a spatial and temporal pattern of expression throughout development that exactly paralleled endogenous POMC. RNase protection assays revealed that POMC27* expression mimicked that of POMC in different areas of the CNS and most peripheral organs with no detectable ectopic expression. Hormonal regulation of POMC27* and POMC was identical in the hypothalamus and pituitary. These results show that distal 5' sequences of the POMC gene located between -13 and $-2 \mathrm{~kb}$ target expression into the CNS of transgenic mice in a precise neuronspecific, developmentally and hormonally regulated manner.

Key words: pro-opiomelanocortin; transgenic mice; gene expression; $\beta$-endorphin; melanocortin; neuron-specific expression; arcuate nucleus; hypothalamus; pituitary
The pro-opiomelanocortin (POMC) gene encodes a multipeptide prohormone that gives rise to various active products after tissuespecific posttranslational processing (Eipper and Mains, 1980). Expression of the POMC gene is limited to a number of cell types of endocrine and neuronal origin, and the physiological role of its derived peptides is to orchestrate the mammalian stress response. Melanotrophs and corticotrophs of the pituitary gland release two of the best characterized POMC-derived peptides, $\alpha$-melanocytestimulating hormone and adrenocorticotropic hormone, respectively (Smith and Funder, 1988). In the CNS, two discrete groups of neurons located in the arcuate nucleus of the hypothalamus

\footnotetext{
Received March 11, 1998; revised June 8, 1998; accepted June 9, 1998.

This research has been supported by grants from the National Institutes of Health/Fogarty International Research Collaborative Award (M.J.L., M.R.), Universidad de Buenos Aires (M.R.), Fundación Antorchas (M.R.), and the International Scholar Program of the Howard Hughes Medical Institute (M.R.). J.I.Y. and M.G.C. received doctoral fellowships from Consejo Nacional de Investigaciones Científicas y Técnicas, Argentina. E.C.C. received a fellowship from the Wollongong Government Employee's Medical Research Fund. We thank the Transgenic Core Facility at Oregon Health Sciences University for valuable assistance with one of the constructs.

Correspondence should be addressed to Dr. Marcelo Rubinstein, Instituto de Investigaciones en Ingeniería Genética y Biología Molecular, Consejo Nacional de Investigaciones Científicas y Técnicas, Vuelta de Obligado 2490, 1428 Buenos Aires, Argentina.

Dr. Chan's present address: Endocrine Unit, John Hunter Hospital, Newcastle, Australia.

Copyright (ㄷ) 1998 Society for Neuroscience $\quad 0270-6474 / 98 / 186631-10 \$ 05.00 / 0$
}

and in the nucleus of the tractus solitarius also express POMC and produce $\beta$-endorphin, a potent opioid peptide that interacts with $\mu$-opioid receptors to mediate stress-induced analgesia ( $\mathrm{Ru}$ binstein et al., 1996) and to regulate reproduction (Seifer and Collins, 1990) and autonomic functions (Olson et al., 1997). In addition to $\beta$-endorphin, POMC-expressing neurons release melanocortin peptides that participate in the control of homeostasis by binding to the central melanocortin receptors MC-3 and MC-4 (Cone et al., 1996; Li et al., 1996). Hypothalamic melanocortins are receiving considerable attention because they seem to regulate feeding and fasting behavior (Fan et al., 1997). Leptin receptors are expressed in POMC hypothalamic neurons (Cheung et al., 1997), and leptin-induced fasting is prevented by melanocortin receptor antagonists (Seeley et al., 1997). In addition, MC-4 receptor agonists reduce food intake (Fan et al., 1997), and MC-4 receptor-deficient mice become obese (Huszar et al., 1997).

The developmental onset of POMC expression follows a distinct temporal pattern (Japón et al., 1994). POMC mRNA is first detected at embryonic day 10.5 (E10.5) in the base of the mouse diencephalon. This early expression preceding all other hypothalamic neuropeptides suggests a developmental role for POMCderived peptides. In the pituitary, POMC mRNA is detected in melanotrophs at E14.5 and in corticotrophs $2 \mathrm{~d}$ earlier, also preceding the expression of all other pituitary hormone genes 
(Japón et al., 1994). Despite the extensive progress that several laboratories achieved to unravel the organogenetic program of the hypothalamic-pituitary axis (Sheng et al., 1997) and to understand the specific commitment of the different cell lineages (Treier and Rosenfeld, 1996), the mechanisms determining POMC cell fate still remain elusive.

Appropriate pituitary expression of reporter transgenes carrying up to $4 \mathrm{~kb}$ of the POMC promoter has allowed the study of tissue-specific expression of POMC in this gland (Liu et al., 1992, 1995). However, all these transgenes failed to recapitulate proper POMC expression in the brain (Rubinstein et al., 1993) (our unpublished results). To study the spatial and temporal regulation of POMC gene expression in the CNS, we produced transgenic mice carrying large fragments of 5' and 3' POMC gene-flanking regions. Here, we report for the first time the accurate targeting of transgenes exclusively to POMC-expressing neurons and that distal 5' sequences of the POMC promoter are required for neuronal-specific expression in the brain.

\section{MATERIALS AND METHODS}

Screening of a mouse genomic library. A mouse cosmid library was constructed by partial MboI digestion of total genomic DNA obtained from $129 / \mathrm{SvEv}$ mouse embryonic stem cells. Size-fractionated fragments were ligated into the Bam HI site of the cosmid vector SuperCos 1 (Stratagene, La Jolla, CA) and then packaged in vitro using Gigapack II XL packaging extracts (Stratagene). Recombinant cosmids were then transfected into Escherichia coli NM554. The final calculated titer of this library was $3 \times$ $10^{5}$ independent clones with an average fragment size of $29 \mathrm{~kb}$. This library was screened at high-stringency hybridization in duplicate nylon filters using simultaneously two ${ }^{32} \mathrm{P}$-labeled, random-primed probes corresponding to the terminal sequences of $\mathrm{pHAL}^{*}$, a mouse genomic POMC clone previously used by us (see Fig. 1) (Rubinstein et al., 1993). We obtained 23 double-positive clones, and two overlapping clones (1 and 13 ) were selected for further subcloning.

DNA constructs. Plasmid POMC27* contains a $27 \mathrm{~kb}$ fragment cloned into the multiple cloning site of pBluescript $\mathrm{SK}+/-$ (Stratagene). It was designed to carry a $30 \mathrm{bp}$ heterologous sequence into POMC exon 3 (Rubinstein et al., 1993) and was obtained after subcloning together pHAL* fragments with flanking sequences taken from two cosmid clones. The $27 \mathrm{~kb}$ fragment was generated by ligating first the Cla IEcoRI fragment of HAL* together with the $17.5 \mathrm{~kb}$ NotI-ClaI fragment of cosmid clone 13 . The final plasmid was completed at the $3^{\prime}$ end with a $6 \mathrm{~kb}$ EcoRI-SmaI fragment obtained from cosmid clone 1 (see Fig. 1). Plasmid $\mathrm{P} 27^{*} 5^{\prime} \Delta$ was constructed by deleting the Not I-EcoRI fragment of POMC27* corresponding to the $5^{\prime}$ region not contained in $\mathrm{pHAL}$ *. The resulting fragment was blunt-ended and religated. Plasmid P27** $3^{\prime} \Delta$ was generated by deleting the EcoRI-SmaI fragment of POMC27* corresponding to the $3^{\prime}$ region not included in $\mathrm{pHAL}^{*}$. The extremes were blunt-ended and religated. The plasmid $\mathrm{rEx}^{*}$ used to make antisense riboprobes was constructed by subcloning the $\mathrm{pHAL}^{*} B g l \mathrm{II}-A p a \mathrm{I}$ exon 3-purified fragment into the multiple cloning site of pBluescript SK $+/-$ (Stratagene).

Production of transgenic mice. Transgenic mice were generated by pronuclear microinjection of $\mathrm{B} 6 \mathrm{CBF} 2$ zygotes through glass capillary micropipettes attached to a manual micromanipulator (Leica, Nussloch, Germany). Fertilized eggs isolated between 9 and 10 A.M., as described elsewhere (Low, 1992), were observed under the differential interference contrast optics of an inverted microscope (FS Labovert, Leica) and microinjected into the most visible pronucleus with $\sim 500$ molecules of the transgene dissolved in $1 \mathrm{pl}$ of a sterile solution containing $5 \mathrm{~mm}$ Tris- $\mathrm{HCl}, \mathrm{pH} 7.4$, and $0.1 \mathrm{~mm}$ EDTA. Transgenes were released from the plasmids by an SalI and Not I double digestion, separated by agarose electrophoresis, collected by electroelution, and purified through an ion-exchange Elutip-D (Schleicher \& Schuell, Keene, NH) column. After microinjection, eggs were transferred to the oviduct of 6- to 10-week-old pseudopregnant Swiss Webster females.

Transgenic mouse identification. Screening for positive transgenic mice was performed by PCR on genomic DNA extracted from tail biopsies. Primers M329 (5'-GAAGTACGTCATGGGTCACT-3') and M330 (5'AGCTCCCTCTTGAACTCTAG-3') amplify a 180 bp band for the wild-type POMC allele and a $210 \mathrm{bp}$ band for a transgenic POMC allele.
DNA was amplified into a 1605 Air Thermo Cycler (Idaho Technology, Idaho Falls, ID) as follows: a first denaturation step at $94^{\circ} \mathrm{C}$ during $5 \mathrm{~min}$ followed by 35 cycles at $94^{\circ} \mathrm{C}$ for $0 \mathrm{sec}, 60^{\circ} \mathrm{C}$ for $10 \mathrm{sec}$, and $72^{\circ} \mathrm{C}$ for 30 sec, with a final elongation step at $72^{\circ} \mathrm{C}$ for $10 \mathrm{~min}$. To confirm transgene integration and to estimate the copy number of each pedigree, we performed Southern blot hybridization of XhoI-Eco RI-digested genomic DNA extracted from tail biopsies. DNA fragments were separated by submarine electrophoresis in a $0.7 \%$ agarose gel and then transferred to a Zeta-Probe nylon membrane (Bio-Rad, Hercules, CA). Blot hybridization was performed using a $0.9-\mathrm{kb}$ Eco RI-HindIII fragment isolated from plasmid $\mathrm{pHAL}^{*}$ and radiolabeled by random priming (Life Technologies, Bethesda, MD) with $\left[\alpha-{ }^{32} \mathrm{P}\right] \mathrm{dCTP}$ (DuPont NEN, Boston, MA). Hybridization was performed at $65^{\circ} \mathrm{C}$ during $16 \mathrm{hr}$ in a solution containing $6 \times$ SSC $(1 \times$ SSC: $0.15 \mathrm{M} \mathrm{NaCl}$ and $0.015 \mathrm{~m} \mathrm{Na}$ citrate, $\mathrm{pH} 7.2), 25 \mathrm{~mm}$ phosphate buffer, $\mathrm{pH} 7.2,5 \times$ Denhardt's solution, $0.5 \%$ SDS, $1 \mathrm{~mm}$ EDTA, pH 8.0, and $100 \mu \mathrm{g} / \mathrm{ml}$ denatured salmon sperm DNA. Blots were then washed in $2 \times \mathrm{SSC}$ and $0.1 \%$ SDS at room temperature twice for $15 \mathrm{~min}$ and then in $0.1 \times \mathrm{SSC}$ and $0.1 \% \mathrm{SDS}$ at $60^{\circ} \mathrm{C}$ and were finally exposed to x-ray film (XAR5; Eastman Kodak, Rochester, NY) using intensifying screens at $-70^{\circ} \mathrm{C}$. The transgene copy number of each line was determined by a scanning densitometric analysis (Gelworks 1D; UVP). Values were interpolated into a concentration curve prepared with mouse control DNA carrying known amounts of the transgenes. F1 mice were analyzed for transgene expression between 6 and 10 weeks of age.

In situ hybridization. In situ hybridizations were performed as described previously (Rubinstein et al., 1993). Adult normal mice or heterozygote transgenic mice were killed by cervical dislocation, and brains and pituitaries were immediately removed and frozen in OCT-containing plastic cubes. Serial coronal sections $(16 \mu \mathrm{m})$ were cut using a cryostat microtome (IEC Microtome, Walldorf, Germany) at $-20^{\circ} \mathrm{C}$. Brain sections included the entire anterior-posterior limits of the arcuate nucleus of the hypothalamus. For developmental in situ hybridization, mouse embryos were collected, and extraembryonic membranes were removed and then frozen, embedded in OCT, and stored at $-70^{\circ} \mathrm{C}$. Sections were thaw-mounted on Vectabond (Vector Laboratories, Burlingame, CA)coated slides and stored at $-70^{\circ} \mathrm{C}$ until used. Sections were fixed in neutral phosphate-buffered $10 \%$ formalin (Sigma, St. Louis, MO) at room temperature for 30 min and washed three times with PBS (in mM: $140 \mathrm{NaCl}, 3 \mathrm{CaCl}_{2}, 10 \mathrm{Na}_{2} \mathrm{HPO}_{4}$, and $1.8 \mathrm{KH}_{2} \mathrm{PO}_{4}$ ) for $10 \mathrm{~min}$ at room temperature, followed by three washes in $2 \times \mathrm{SSC}$ for $10 \mathrm{~min}$ at room temperature. Slides were drained 5-10 $\mathrm{min}$ and then incubated under parafilm coverslips with $35-50 \mu \mathrm{l}$ of a solution containing $50 \%$ formamide, $4 \times$ SSC, $1 \times$ Denhardt's solution, $250 \mu \mathrm{g} / \mathrm{ml}$ yeast tRNA, 500 $\mu \mathrm{g} / \mathrm{ml}$ sheared and denatured salmon sperm DNA, $10 \mathrm{~mm}$ dithiothreitol, and $10 \%$ dextran sulfate at $37^{\circ} \mathrm{C}$ for $1 \mathrm{hr}$. Slides were drained again and incubated overnight at $37^{\circ} \mathrm{C}$ with prehybridization solution containing $11,000-20,000 \mathrm{cpm} / \mu$ l oligonucleotide probe. Slides were washed four times with $1 \times \mathrm{SSC}$ and $1 \mathrm{~mm}$ dithithreitol for $15 \mathrm{~min}$ at room temperature followed by four washes with $2 \times$ SSC and $50 \%$ formamide for 15 $\min$ at $37^{\circ} \mathrm{C}$. Finally, slides were washed three times with $1 \times \mathrm{SSC}$ for 30 min at room temperature. After a quick rinse in water, slides were dehydrated through 5 min steps in ethanol at 70, 95, and $100 \%$, dried at room temperature, dipped in Kodak N-TB3 emulsion (diluted 1:1 in distilled water), and exposed for 14-19 d. Slides were developed, counterstained with neutral red (Sigma), and coverslipped under Permount (Fisher Scientific, Pittsburgh, PA). Radiolabeled probes were generated by incubating 5 pmol of synthetic oligodeoxynucleotides with $50 \mathrm{pmol}$ of $\alpha\left[{ }^{35} \mathrm{~S}\right] \mathrm{dATP}(1300 \mathrm{Ci} / \mathrm{mmol}$; DuPont NEN) and $50 \mathrm{U}$ of terminal deoxynucleotidyltransferase (Life Technologies). To detect both the endogenous POMC mRNA and the transgenic transcripts we used a $30 \mathrm{mer}$ antisense to exon 2 (E2-POMC, 5'-CCCTGAGCGACTGTAGCAGAATCTCCGGCAT- $3^{\prime}$ ), whereas to detect specifically the transgenic transcripts we used 553-TG, a 30 mer antisense to the inserted oligonucleotide described above (553-TG, 5'-CGCGATAGCAGACTCGAGAGCGACAGACAG-3'). To detect specifically the endogenous transcript, we used E3-POMC, a 30 mer antisense to the POMC region that surrounds the insertion site (E3-POMC, 5'-CGGAAGTGCTCCATGGAGTAGGAGAGCGCTTG-3').

RNA extraction. Cytoplasmic RNA was prepared from individual mouse hypothalami and pituitaries as follows: $0.5-2 \mathrm{mg}$ of frozen tissue was homogenized using a $1 \mathrm{ml}$ syringe with a 25 ga needle in a buffer containing $0.01 \mathrm{M}$ Tris- $\mathrm{HCl}, \mathrm{pH} 7.0,0.15 \mathrm{M} \mathrm{NaCl}, 2 \mathrm{~mm} \mathrm{MgCl}_{2}, 1.2 \%$ Nonidet P-40 (Sigma), and $10 \mathrm{U}$ of RNasin (Sigma). The extract was centrifuged at $10,000 \times g$ for $5 \mathrm{~min}$ at $4^{\circ} \mathrm{C}$. One volume of a solution 
containing $0.01 \mathrm{~mm}$ Tris-HCl, pH 7.6, $0.15 \mathrm{~m} \mathrm{NaCl}, 5 \mathrm{~mm}$ EDTA, and $1.2 \%$ SDS was added to the supernatant and mixed by vortexing, and an equal volume of phenol:isoamyl alcohol:chloroform (50:1:50) was added. The emulsion was centrifuged at $10,000 \times g$ at $4^{\circ} \mathrm{C}$ for $10 \mathrm{~min}$. Cytoplasmic RNA was isolated from the aqueous phase by centrifugation in $0.3 \mathrm{M}$ sodium acetate and $70 \%$ ethanol. After washing and drying, the precipitate was redissolved in sterile water and stored at $-70^{\circ} \mathrm{C}$ until used. Total RNA was isolated from other tissues by the acid-guanidinium thiocyanate-acid-phenol method (Chomczynski and Sacchi, 1987), and RNA concentration was determined by UV absorption at $260 \mathrm{~nm}$.

Ribonuclease protection assay. Antisense cRNA probes were produced by in vitro transcription of $\mathrm{rEx} 3^{*}$, a plasmid containing a mouse POMC genomic insert that encompasses the entire exon 3, including the heterologous $30 \mathrm{bp}$ inserted originally into the NcoI site (Rubinstein et al., 1993). rEx3* was linearized with XhoI and then subjected to in vitro transcription using T7 RNA polymerase as described by the manufacturer (Gemini; Promega, Madison, WI). Uniformly labeled riboprobes were generated using $\left[\alpha^{-32} \mathrm{P}\right] \mathrm{UTP}$, and full-length 214 nucleotide transcripts were isolated after running a vertical PAGE. The radiolabeled riboprobe was eluted, quantified, and incubated with the totality of extracted RNA in the case of hypothalamus or with fractions in the case of other tissues. To normalize among samples, a mouse $\beta$-actin riboprobe was also included in all reactions and prepared after in vitro transcription of a linearized plasmid supplied with the RPA II ribonuclease protection assay kit (Ambion, Austin, TX). RNA samples and probes were coprecipitated in $0.5 \mathrm{M}$ ammonium acetate and $70 \%$ ethanol, and the resulting pellets were resuspended in the hybridization buffer supplied with the kit. Reaction mixtures were denatured for $5 \mathrm{~min}$ at $90^{\circ} \mathrm{C}$ and then incubated overnight at $43^{\circ} \mathrm{C}$ to allow hybridizations to occur. Unhybridized singlestranded RNA was digested by a mixture of $4 \mathrm{U} / \mathrm{ml}$ RNase A and $15 \mathrm{U} / \mathrm{ml}$ RNase T1 in digestion buffer supplied by the manufacturer at room temperature for $30 \mathrm{~min}$. Protected fragments were precipitated, and RNase activities were halted by adding an RNase inactivation-precipitation mixture. The protected cRNA-mRNA hybrids containing mRNA transcribed from the endogenous POMC gene (185 bases), from the transgenes (199 bases), and from the mouse $\beta$-actin gene (300 bases) were separated by electrophoresis in $5 \%$ polyacrylamide denaturing gels in Tris-borate-EDTA $(0.9 \mathrm{M}$ Tris- $\mathrm{HCl}, 0.9 \mathrm{M}$ boric acid, and $20 \mathrm{~mm}$ EDTA) buffer. The experimental design is depicted in Figure $5 A$. The gels were exposed via direct contact autoradiography, and individual bands were quantified by determining their total integrated optical density using an LKB-Wallac densitometer.

Colocalization of transgenic $m R N A$ and $\beta$-endorphin. Simultaneous in situ detection of transgenic POMC27* mRNA and $\beta$-endorphin was achieved by in situ hybridization using the deoxyoligonucleotide probe 553-TG followed by immunocytochemistry using a $\beta$-endorphin antiserum (Rubinstein et al., 1996). Slides previously subjected to in situ hybridization, exposed and developed as described above, were immersed in toluene to remove the coverslips and then dipped in a freshly prepared $0.2 \%(\mathrm{w} / \mathrm{v})$ trypsin solution in PBS, $0.01 \mathrm{M}, \mathrm{pH} 7.2$, for $30 \mathrm{sec}$. The slides were washed twice in PBS for $45 \mathrm{~min}$ followed by $30 \mathrm{~min}$ in KPBS $\left(0.9 \% \mathrm{NaCl}, 16 \mathrm{mM} \mathrm{K}_{2} \mathrm{HPO}_{4}\right.$, and $\left.3.6 \mathrm{mM} \mathrm{KH}_{2} \mathrm{PO}_{4}\right)$ and then in KPBS and $1 \% \mathrm{H}_{2} \mathrm{O}_{2}$ for $20 \mathrm{~min}$ and finally were rinsed three times in KPBS for 5 min. Slides were then preincubated in KPBS-0.3\% Triton X-100-2\% normal goat serum at room temperature for $2 \mathrm{hr}$ and then incubated overnight at $4^{\circ} \mathrm{C}$ with a $\beta$-endorphin antiserum $(1: 1000$ in KPBS, $0.3 \%$ Triton X-100, and $2 \%$ normal goat serum). After washing with KPBS two times for $20 \mathrm{~min}$, antigen-antibody complexes were incubated with a biotinylated goat anti-rabbit IgG solution (Sigma) (1:200 in KPBS and $0.3 \%$ Triton X-100) for $2 \mathrm{hr}$ at room temperature and then washed twice with KPBS for $20 \mathrm{~min}$. Finally, slides were incubated with avidin-peroxidase (1:1000 in KPBS, $0.3 \%$ Triton X-100, and $0.1 \%$ bovine serum albumin) for $1 \mathrm{hr}$, rinsed in TBS $(50 \mathrm{~mm}$ Tris- $\mathrm{HCl}$ and $150 \mathrm{~mm} \mathrm{NaCl}, \mathrm{pH} 7.5$ ), and incubated with diaminobenzidine $\left(25 \mathrm{mg} / \mathrm{ml}\right.$ in TBS, $\left.0.05 \% \mathrm{H}_{2} \mathrm{O}_{2}\right)$. The reaction was stopped by dipping the slides in TBS. Slides first dehydrated in ethanol 70, 95, and $100 \%$, followed by xylene, were then coverslipped under Permount.

Restraint stress paradigm. Stress was applied by a $1 \mathrm{hr}$ immobilization. Each animal was inserted into a plastic cylindrical device, which could be adapted to the size of the animal, between 10:30 and 11:30 A.M. for 5 consecutive days. Adhesive tape was used to tightly close the tube. Immediately after the end of the last restraint session, experimental and control animals were killed, and the tissues were collected.

Surgical procedures. Bilateral adrenalectomies and castrations were performed under tribromoethanol anesthesia $(300 \mathrm{mg} / \mathrm{kg}$, i.p.). Mice

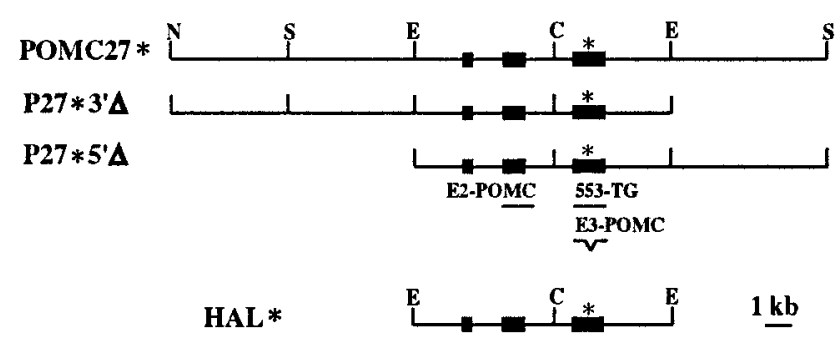

Figure 1. Structure of POMC transgenes. POMC27* is a $27 \mathrm{~kb}$ genomic fragment that contains the entire transcriptional unit of the mouse POMC gene together with $13 \mathrm{~kb}$ of $5^{\prime}$ flanking sequences and $8 \mathrm{~kb}$ of $3^{\prime}$ flanking sequences. $\mathrm{P} 27^{*} 3^{\prime} \Delta$ carries only $2 \mathrm{~kb}$ of mouse POMC $3^{\prime}$ flanking sequences, whereas $\mathrm{P} 27^{*} 5^{\prime} \Delta$ carries only $2 \mathrm{~kb}$ of $5^{\prime}$ flanking sequences. $\mathrm{HAL}^{*}$ is a $10.2 \mathrm{~kb}$ genomic fragment that contains the entire transcriptional unit of the mouse POMC gene together with $2 \mathrm{~kb}$ of $5^{\prime}$ and $3^{\prime}$ flanking sequences. The asterisk depicted in all transgenes indicates a 30 bp heterologous sequence inserted into the unique NcoI site present in exon 3, as described in Materials and Methods. Black boxes indicate exon sequences. E2-POMC, 553-TG, and E3-POMC indicate the positions of the oligonucleotides used for expression analysis. $C, C l a \mathrm{I} ; E, E c o$ RI; $S$, SmaI; N, NotI.

subjected to adrenalectomy were supplemented with $0.9 \% \mathrm{NaCl}$ or received a replacement dose of dexamethasone (Sigma; $50 \mu \mathrm{g} / \mathrm{ml}$ in $0.9 \%$ $\mathrm{NaCl}$ ) in their drinking water for $5 \mathrm{~d}$. At the fifth day, mice were killed by cervical dislocation, and tissues were removed. Mice subjected to bilateral orchiectomy were killed by cervical dislocation 3 weeks after the surgical procedures. For the ontogenic studies, timed pregnant females checked by a morning vaginal plug were killed by cervical dislocation at $1 \mathrm{~d}$ intervals starting at E9.5, and the embryos were removed and analyzed macroscopically to confirm developmental staging.

Drug treatments. POMC27* transgenic mice housed in groups of five received two daily subcutaneous injections (at 7 A.M. and 7 P.M.) of 1 $\mathrm{mg} / \mathrm{kg}$ apomorphine (Laboratoires Meram), $1 \mathrm{mg} / \mathrm{kg}$ haloperidol (Janssen Farmaceutica, Buenos Aires, Argentina), or vehicle for 5 d. All animals were killed by cervical dislocation $1 \mathrm{hr}$ after the last injection, and tissues were immediately removed.

\section{RESULTS}

\section{Neuron-specific expression of POMC genomic fragments in transgenic mice}

We constructed and screened a 129/SvEv mouse genomic library and obtained two overlapping cosmid clones that covered $27 \mathrm{~kb}$ of the POMC locus. These fragments were used to generate POMC27* $^{*}$, a transgene that contained the entire $6 \mathrm{~kb}$ of the POMC transcriptional unit together with $13 \mathrm{~kb}$ of $5^{\prime}$ flanking regions and $8 \mathrm{~kb}$ of $3^{\prime}$ flanking regions. To follow the expression of the transgene unequivocally from that of the endogenous mouse POMC gene by in situ hybridization, we inserted a doublestranded 30 mer oligonucleotide at the unique $\mathrm{Nco}$ I site present in exon 3 (Fig. 1). Microinjection of POMC27* into the pronuclei of B6CBF1 mouse zygotes originated three independent transgenic pedigrees. Analysis of the expression of the transgene in comparison with that of the endogenous POMC gene was performed on $16 \mu \mathrm{m}$ cryostat coronal sections of brains and pituitaries obtained from F1 transgenic and nontransgenic littermates from the three lines.

Detection of the genuine mouse POMC mRNA was performed by using E3-POMC, an antisense 30 mer oligonucleotide probe designed against the 15 nucleotides that flank both sides of the NcoI site present in exon 3. Preliminary hybridization studies performed under stringent conditions with plasmid DNA transferred to nylon membranes showed that this probe hybridized with fragments carrying the wild-type exon 3 but failed to hybridize to $\mathrm{POMC} 27^{*}$, resulting in an efficient tool to detect only 
E3-POMC
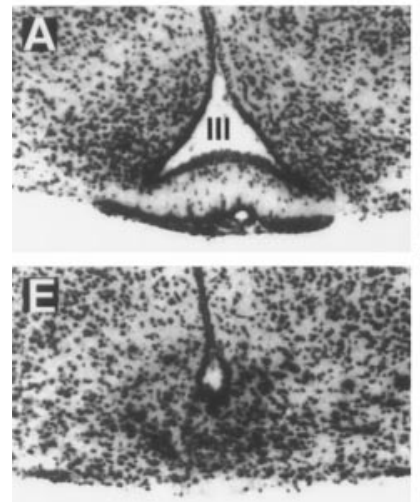
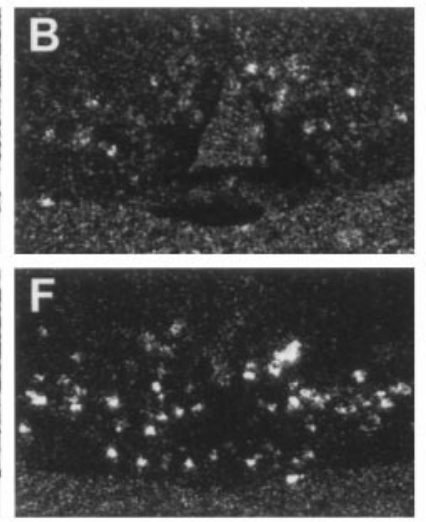

553-TG
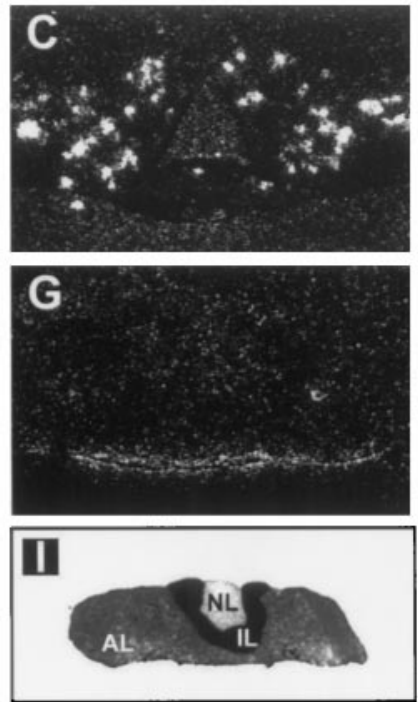

E2-POMC
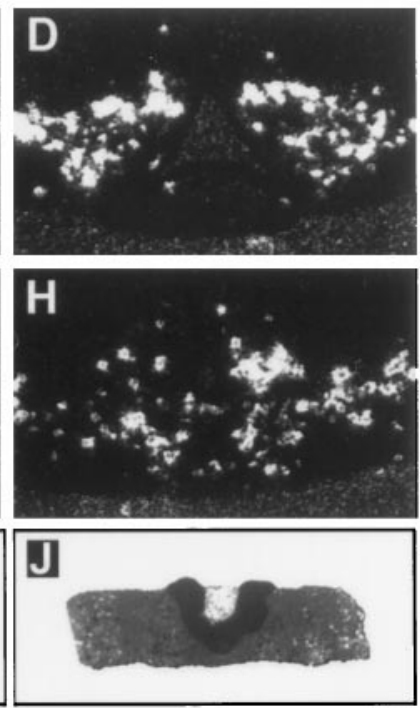

Figure 2. Localization of POMC and POMC27* mRNA in hypothalamic and pituitary sections by in situ hybridization. Alternate $16 \mu \mathrm{m}$ coronal sections taken at the level of the mediobasal hypothalamus of POMC27* transgenic $(A-D)$ and nontransgenic $(E-H)$ mice were hybridized with $\alpha-{ }^{35}$ S-labeled 30 bp oligonucleotides. Similarly, pituitary sections were taken from a POMC27* transgenic mouse $(I, J)$. Probe E3-POMC detects only endogenous POMC mRNA $(B, F)$. Probe 553-TG detects only transgenic POMC27* mRNA $(C, G, I)$, and probe E2-POMC recognizes both endogenous and transgenic POMC mRNAs $(D, H, J)$. Dark-field photomicrographs show endogenous and transgenic expression in neurons of the arcuate nucleus of the hypothalamus. Cellular architecture of this brain region stained with neutral red is shown in the bright-field photographs on the left ( $A$, $E$ ). Magnification, $40 \times$.

endogenous POMC mRNA (data not shown). E3-POMC revealed the identical distribution of POMC-expressing neurons in the arcuate nucleus of the medial basal hypothalamus of transgenic mice (Fig. 2A,B) and their nontransgenic siblings (Fig. $2 E, F)$. Detection of transgenic expression was performed by the use of 553-TG, an antisense oligonucleotide designed against the heterologous $30 \mathrm{bp}$ sequence inserted at the NcoI site. In situ hybridization performed on brain coronal slices with 553-TG showed POMC27* expression only in the hypothalamus of transgenic mice (Fig. 2, compare $C, G$ ) with a qualitative and quantitative pattern similar to that found for the endogenous POMC mRNA (Fig. 2B). This result suggested an appropriate expression of the transgene POMC27* in POMC neurons. A 30 mer probe designed against exon 2 sequences (E2-POMC) that hybridizes with the endogenous POMC mRNA as well as with the transgenic POMC27* mRNA showed an identical spatial pattern of expression, although it exhibited a higher hybridization signal. This quantitative difference reflected, in part, the additive contribution of the wild-type and the transgenic mRNAs to this signal (Fig. $2 D)$. Nonetheless, we also noted that the in situ signal obtained with E2-POMC was consistently higher than that observed with E3-POMC in serial sections of nontransgenic mice (Fig. 2, compare $F, H$ ), suggesting a higher in situ accessibility of E2-POMC for POMC-derived mRNA despite sharing similar thermodynamic properties with E3-POMC (Tm, 82.2 and $84.8^{\circ} \mathrm{C}$, respectively). The transgene is also efficiently targeted to endocrine cells of the intermediate and anterior lobes of the pituitary gland (Fig. $2 I, J)$. The results shown in Figure 2 correspond to tissue sections taken from male mice. The same pattern of distribution for the transgenic and endogenous POMC mRNAs was also observed in female mice.

To further confirm that arcuate neurons labeled with 553-TG corresponded to genuine POMC-expressing cells, we performed a colocalization experiment by combining in situ hybridization
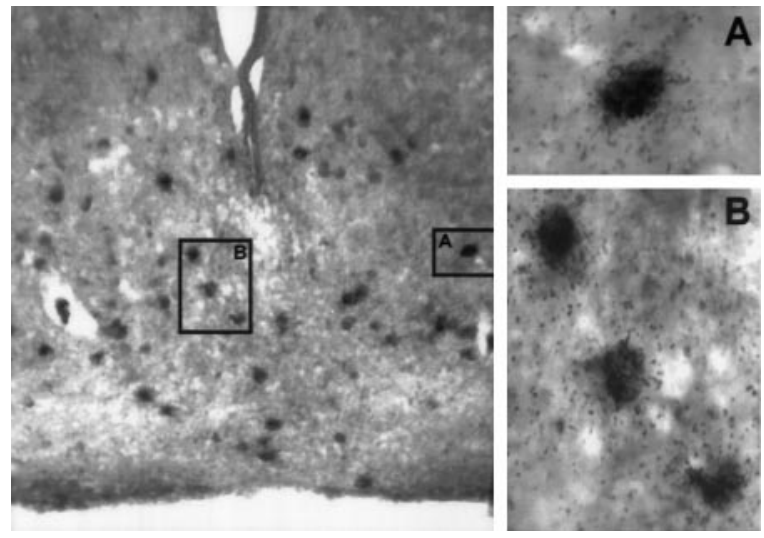

Figure 3. Colocalization of transgenic POMC27* mRNA and $\beta$-endorphin immunoreactivity on neurons of the arcuate nucleus of the hypothalamus. Left, Representative $20 \mu \mathrm{m}$ coronal section taken from the mediobasal hypothalamus of a POMC27* transgenic mouse that was subjected first to in situ hybridization using probe 553-TG and then to immunolabeling with a $\beta$-endorphin antiserum. Immunoreactivity was detected using diaminobenzidine as described in Materials and Methods. Magnification, $100 \times$. Right, $A, B$, Representative areas of the arcuate nucleus section on the left at a $400 \times$ magnification scale.

with 553-TG followed by immunocytochemical labeling with a $\beta$-endorphin antiserum. Silver grains deposited on cell bodies were only detected on neurons that immunoreacted with the $\beta$-endorphin antiserum, demonstrating that transgenic expression from POMC27* was accurate and limited to POMC-producing cells in the hypothalamus (Fig. 3). We have not detected ectopic expression sites anywhere in the brain in all transgenic lines analyzed. This result validated the assumption that POMC27* contains strong neuron-specific sequences to target transgene expression to neurons of the POMC lineage. 


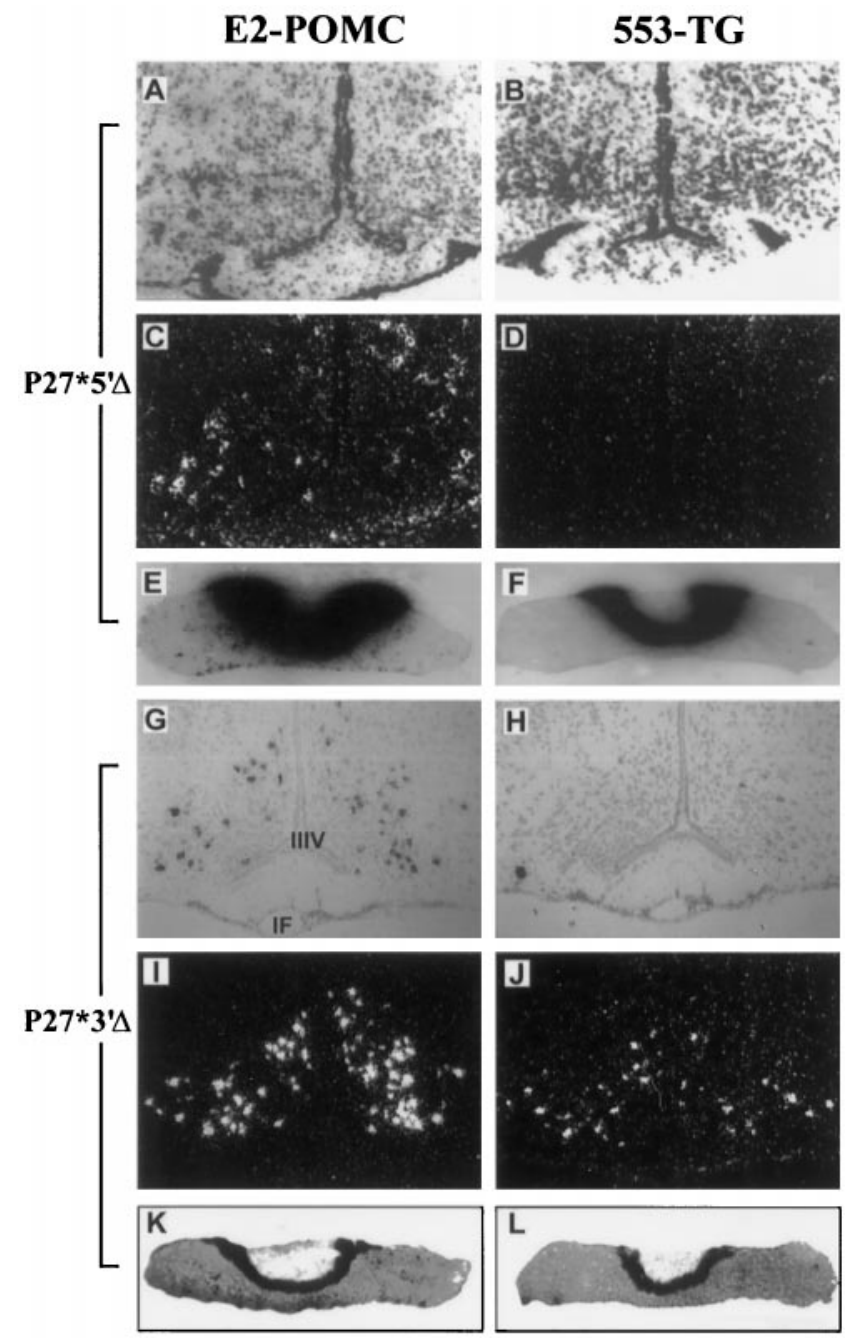

Figure 4. Neuron-specific expression of the POMC gene is controlled by distal $5^{\prime}$ flanking sequences. Expression analysis of $\mathrm{P} 27^{*} 5^{\prime} \Delta(A-F)$ and $\mathrm{P} 27^{*} 3^{\prime} \Delta(G-L)$ transgenic mice by in situ hybridization performed on alternate coronal sections of the mediobasal hypothalamus $(A-D, G-J)$ or the pituitary $(E, F, K, L)$. Left, Sections incubated with an $\alpha-{ }^{35}$ S-labeled E2-POMC probe. Right, Sections incubated with an $\alpha-{ }^{35}$ S-labeled 553-TG probe. Bright-field photographs show neutral red-stained sections $(A, B$, $E-H, K, L)$. The same sections under dark field allowed a clearer detection of the silver grain signal $(C, D, I, J)$. Magnification, $40 \times$.

\section{The distal $5^{\prime}$ flanking region of POMC is required for expression in the CNS}

In a previous report, we showed that a $10.2 \mathrm{~kb}$ mouse POMC genomic fragment that contained $2 \mathrm{~kb}$ of $5^{\prime}$ flanking sequences together with $2 \mathrm{~kb}$ of $3^{\prime}$ flanking sequences (Fig. 1, $H A L^{*}$ ) failed to direct proper expression to POMC neurons in transgenic mice (Rubinstein et al., 1993). A comparison of the expression pattern achieved with $\mathrm{POMC} 27^{*}$ in relation to that previously observed with HAL* (Fig. 1) indicated that additional 5' or $3^{\prime}$ flanking sequences would contain the necessary elements to target transgenic expression to POMC-producing neurons. To evaluate whether these elements would reside on the $5^{\prime}$ or the $3^{\prime}$ arm, we generated transgenic mice carrying either a $3^{\prime}$ truncated version of POMC27* named P27*3' $\Delta$ or a $5^{\prime}$ version of POMC27* named $\mathrm{P} 27^{*} 5^{\prime} \Delta$ (Fig. 1). Deletion of the $5^{\prime}$ flanking sequences resulted in a complete lack of neuronal expression in the brain of transgenic mice from three independent lines analyzed (Fig. $4 A-D$ ). Inter-

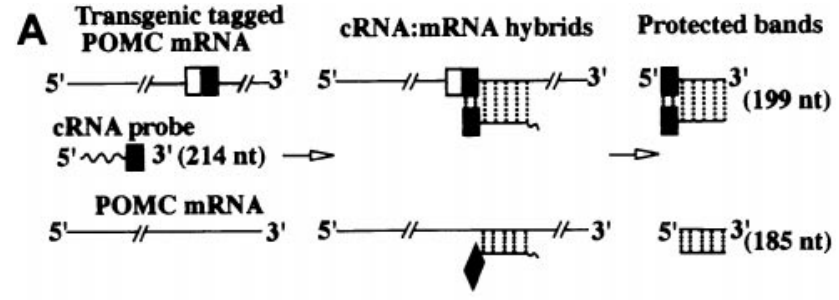

B

POMC27*

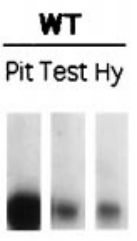

$\beta$-actin

Figure 5. Simultaneous detection of POMC and POMC27* mRNA in different tissues of transgenic mice by an RNase protection strategy. $A$, Description of the RNase protection assay developed to detect simultaneously both POMC mRNA forms isolated from single tissues as described in Results. The white and black squares denote the $30 \mathrm{bp}$ heterologous oligonucleotide inserted in exon 3. The black squares depict the 15 -nucleotide portion that hybridizes to the riboprobe. $B$, Cytoplasmatic RNA samples isolated from different tissues of POMC27* transgenic and wild-type $(W T)$ mice were subjected to an RNase protection assay using a mouse POMC* $^{*}$ exon 3 riboprobe. A mouse $\beta$-actin riboprobe was included in all protection reactions as an internal control. Pit, Pituitary; $A L$, anterior lobe; $B S$, brainstem; $R B$, rest of brain; $B C$, brain cortex; $H y$, hypothalamus; Cer, cerebellum; Test, testis; Ser, serum; Ova, ovary; $\mathrm{Spl}$, spleen.

estingly, appropriate expression of $\mathrm{P} 27^{*} 5^{\prime} \Delta$ in the pituitary gland was observed in mice from the three lines generated (Fig. $4 E-F$ ) with lower levels of the transgenic mRNA in comparison with POMC mRNA in the anterior lobe. This result demonstrates directly that the control of brain and pituitary expression of the POMC gene is exerted by independent mechanisms. Conversely, deletion of the $3^{\prime}$ flanking sequences of POMC27* did not affect the efficient targeting of the transgene to POMC-expressing neurons or the pituitary (Fig. $4 G-L$ ). The neuronal expression pattern of the transgene $\mathrm{P} 27^{*} 3^{\prime} \Delta$ was determined by in situ hybridization in coronal brain slices and shown to be identical to that observed for the endogenous POMC gene in the two independent pedigrees generated (Fig. 4G-J). These results indicated that critical neuron-specific elements are localized within an $11 \mathrm{~kb}$ stretch of distal 5' sequences from the POMC gene.

\section{Quantitative analysis of POMC27* transgene expression in different tissues}

To analyze both the spatial expression pattern and steady-state levels of POMC27* mRNA, we developed an RNase protection assay sensitive enough to detect simultaneously endogenous and transgenic POMC mRNAs from single tissue samples. The presence of the double-stranded $30 \mathrm{bp}$ heterologous sequence inserted in the coding region of POMC27* exon 3 allowed us to use a unique radiolabeled 214-nucleotide riboprobe to perform a relative quantitative analysis between the 185-nucleotide band protected by endogenous POMC mRNA and the 199-nucleotide band protected by transgenic POMC27* mRNA (Fig. 5A). A riboprobe directed to the mouse $\beta$-actin mRNA was included in all incubations as an internal control. Tissues obtained from several transgenic and control mice were monitored for the presence of the two POMC mRNA forms. As expected, total RNA 
extracted from tissues known to express the POMC gene such as the pituitary, the hypothalamus, and testes from wild-type mice protected a single band of 185 nucleotides (Fig. 5B, right). When RNA was prepared from tissues obtained from POMC27* transgenic mice, an additional protected band of 199 nucleotides was evident, revealing the presence of transgenic mRNA. An analysis across a wide variety of tissues showed an almost complete overlap of expression for both mRNAs (Fig. 5B). POMC and POMC27* mRNA were detected in all brain regions analyzed, including hypothalamus, brain cortex, cerebellum, brainstem, and the rest of brain (Fig. 5B). Both POMC mRNA forms were also detected in the testes and the spleen. However, in the ovaries and serum we only detected the shorter protected band that corresponded to endogenous POMC (Fig. 5B). A similar result was obtained with skin samples taken from the flanks of the animals (data not shown). Total RNA isolated from other tissues such as liver, skeletal muscle, and heart failed to protect either band (data not shown). In conclusion, over the complete range of tissues analyzed, the expression of the transgene POMC27* paralleled almost entirely that of the endogenous gene with no ectopic expression detected by this sensitive method.

\section{Developmental expression of POMC27*}

The ontogenic program of POMC gene expression is rather complex. To test whether POMC27* was under the same restricted temporal and spatial pattern of expression as the mouse POMC gene, we set up timed pregnancies and collected embryos for consecutive days starting at E9.5. In situ hybridization of sagittal and coronal slices of mouse embryos revealed that the expression of POMC27* followed an identical developmental pattern of expression to the endogenous POMC mRNA (Fig. 6). As early as E10.5, transgenic signal was observed in a region of the basal diencephalon that will give rise to the developing arcuate nucleus, in agreement with what has been previously observed for the onset of POMC gene expression (Japón et al., 1994). In addition, POMC $27^{*}$ mRNA was also clearly detected in the base of the fourth ventricle (Fig. $6 A-C$ ) and in the neuroepithelium of the neural tube (Fig. $6 D-F$ ), regions that will develop into the brainstem and the lower spinal cord, respectively. At E13.5 POMC27* expression was observed in the primitive anterior lobe of the pituitary gland (Fig. $6 G-I$ ), and $1 \mathrm{~d}$ later cells of the intermediate lobe were also evident (Fig. $6 J-L$ ). Coronal sections of the pituitary at E17.5 showed the ventromedial to dorsolateral migration of the transgene after the typical recruitment of this cell type within the developing anterior lobe (Fig. $6 M-O)$. POMC expression in neurons of the nucleus of the tractus solitarius was detected at E17.5 in coronal sections, and that of the transgene was identical (Fig. $6 P-R$ ). No ectopic expression of the transgene was detected throughout development.

\section{Hormonal regulation of POMC27* expression in the pituitary and brain of transgenic mice}

POMC gene expression is highly regulated by neurotransmitters and hormones. Melanotrophs of the intermediate lobe are negatively regulated by tuberoinf undibular dopamine release, whereas glucocorticoids inhibit POMC transcription in corticotrophs of the anterior lobe. In the hypothalamus, POMC gene expression has been reported to be regulated by neurotransmitters and hormones that participate in the stress response (Baubet et al., 1994) and in reproductive function (Matera and Wardlaw, 1994). To determine whether the cis-acting elements present in POMC27* would account for the hormonal regulation of the gene in the different pituitary cell types and in the hypothalamus, we performed the following series of experiments on transgenic mice from one of the POMC27* pedigrees. Mice were killed after pharmacological or surgical manipulations, and total RNA was obtained from single neurointermediate and anterior pituitary lobes as well as from single hypothalami for analysis with the RNase protection strategy described above.

The dopamine receptor blocker haloperidol administered twice a day for 5 consecutive days induced a twofold increase in the levels of both POMC mRNA forms isolated from the neurointermediate pituitary lobe (Fig. $7 A$ ). However, the dopamine receptor agonist apomorphine given for 5 consecutive days failed to modify the expression levels of melanotrophic POMC or POMC27*. Interestingly, a densitometric scanning analysis determined that the relative levels of the bands protected by POMC and POMC27* mRNA were almost identical in all treatments, including the control animals receiving saline (Fig. $7 A$ ). These results suggest that the transcriptional strength of the transgene in melanotrophs mirrors that of the endogenous gene. The treatment with dopaminergic agents did not modify the mRNA content for either POMC form in the anterior lobe (data not shown) or in the hypothalamus (Fig. $7 C$ ). In the anterior lobe, we found that the levels of transgenic POMC27* mRNA were significantly lower that those seen for POMC in all lines analyzed. Nonetheless, bilateral adrenalectomy induced an almost threefold increase in the levels of POMC in this lobe for both mRNAs (Fig. 7B). Mice receiving dexamethasone replacement experienced a significant reduction in the mRNA contents of both POMC products (Fig. $7 B$ ). We then studied the regulation of POMC gene expression in the arcuate nucleus of the hypothalamus. Gonadal steroids mediate the negative control of hypothalamic gonadotropinreleasing hormone secretion through a pathway that involves the participation of the POMC product $\beta$-endorphin (Matera and Wardlaw, 1994; Olson et al., 1997). Steroid modulation of POMC gene expression has been implicated in such a mechanism (Yang and Lim, 1995). To this end, bilateral orchiectomies were performed in transgenic and nontransgenic mice that were killed $21 \mathrm{~d}$ after surgery. Contrary to what has been reported in rats, castration failed to produce a significant effect on the contents of either POMC mRNA species (Fig. 7C). We then evaluated whether repetitive stressful stimuli would modify hypothalamic POMC mRNA levels in mice as it had been reported in rats (Baubet et al., 1994). Mice were stressed by immobilization for $1 \mathrm{hr}$ during 5 consecutive days and killed immediately after receiving the 10th session. We found that the expression levels of POMC and POMC27* were not significantly modified following this paradigm (Fig. 7C). Interestingly enough, the relative levels of POMC and POMC27* mRNA in the hypothalamus of transgenic mice were identical, suggesting that expression from the transgene paralleled that of POMC in a quantitative as well as in a qualitative manner, similar to what we observed in the neurointermediate lobe.

\section{DISCUSSION}

For the first time we show targeted expression of transgenes exclusively to POMC neurons of the CNS under an accurate spatial and temporal control. Expression of transgenes carrying POMC gene-flanking sequences was clearly detected in POMCproducing cells of the arcuate nucleus of the hypothalamus as well in the developing diencephalon, spinal cord, and nucleus of the tractus solitarius. The cis-acting elements necessary for this efficient targeting were localized within $11 \mathrm{~kb}$ of distal sequences of 


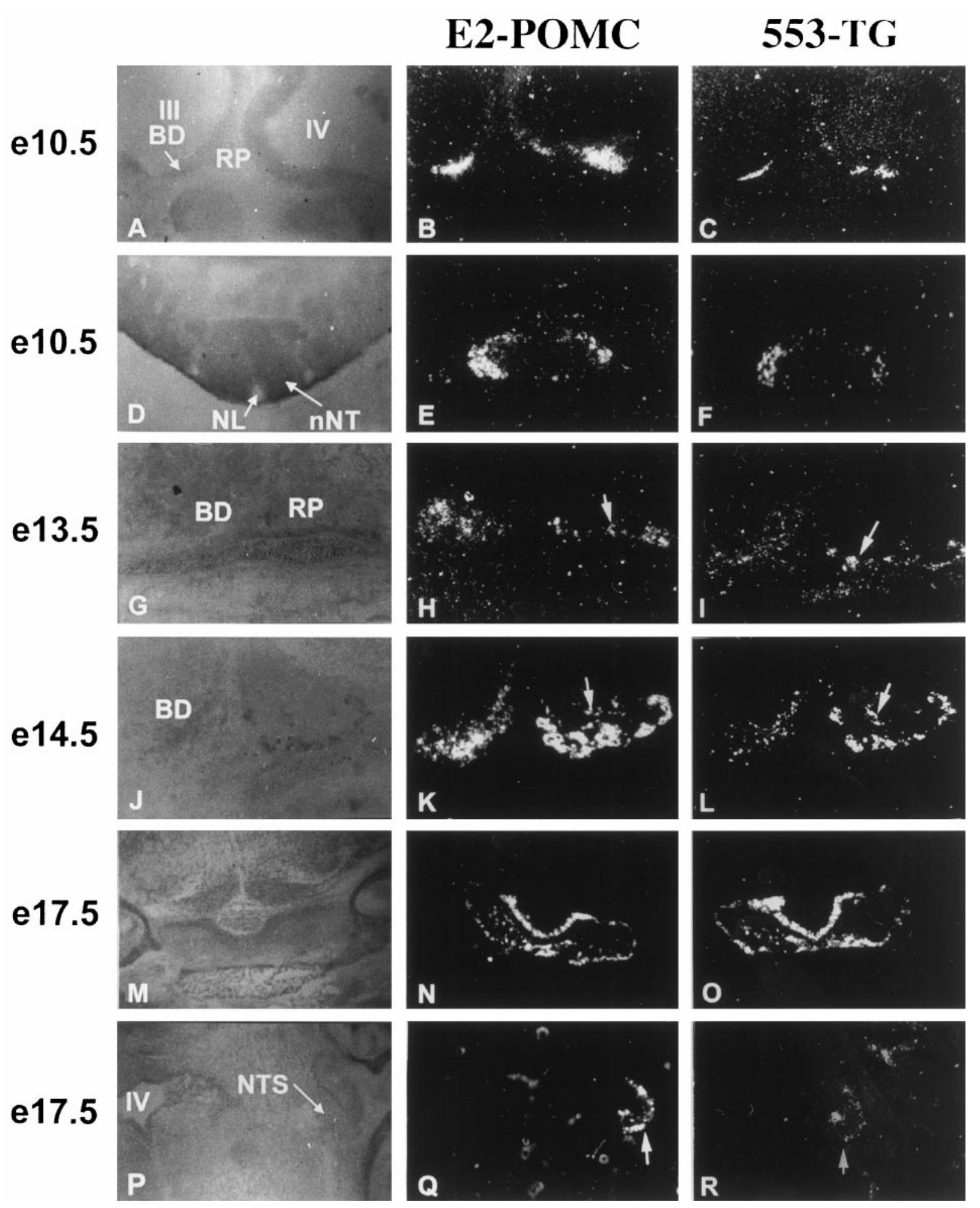

Figure 6. Developmental analysis of POMC and POMC27* expression in transgenic mice. Dark-field photomicrographs of endogenous POMC and transgenic POMC27* mRNA detected by in situ hybridization using $[\alpha]^{35}$ S-labeled oligonucleotide probes on sections of mouse embryos collected at E10.5, E13.5, E14.5, and E17.5. Probe 553-TG (right column) detects only transgenic POMC27* expression, and probe E2-POMC (middle column) detects the endogenous and transgenic mRNA simultaneously. $A-L$ were cut using a sagittal orientation, $M-O$ were cut in a coronal plane, and $P-R$ were taken on a horizontal plane. Bright-field photographs of embryo sections stained with neutral red are shown on the left column for anatomical reference. III, Third ventricle; $I V$, fourth ventricle; $B D$, basal diencephalon; $R P$, Rathke's pouch; $N L$, neural lumen; $n N T$, neuroepithelium of neural tube; $N T S$, nucleus of the tractus solitarius. Arrows in $H$ and $I$ identify anterior lobe corticotrophic cells, whereas arrows in $K$ and $L$ indicate intermediate lobe melanotrophic cells. Arrows in $Q$ and $R$ are pointing at cells from the nucleus of the tractus solitarius. Magnifications: $A-F, M-R, 40 \times ; G-L, 100 \times$. 

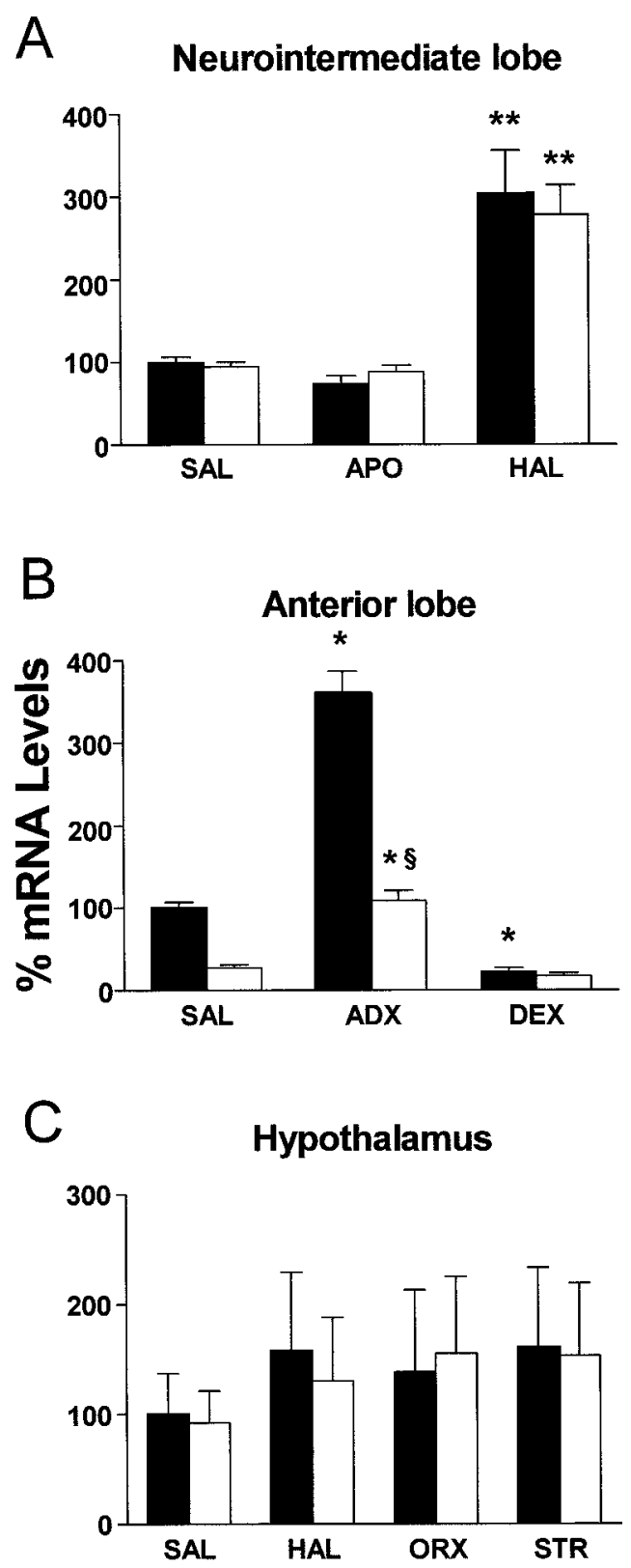

Figure 7. Hormonal regulation of $\mathrm{POMC}$ and $\mathrm{POMC} 27^{*}$ in transgenic mice. Detection and quantification of POMC and POMC27* mRNA by RNase protection followed by densitometric scanning of single tissue samples isolated from POMC27* transgenic mice receiving different drug or surgical treatments. $A$, Neurointermediate lobe samples taken from mice receiving saline $(S A L), 1 \mathrm{mg} / \mathrm{kg}$ apomorphine subcutaneously $(A P O)$, or $1 \mathrm{mg} / \mathrm{kg}$ haloperidol subcutaneously $(H A L)$ twice daily during 5 consecutive days. $B$, Anterior lobe samples taken from sham-operated mice receiving daily injections of saline $(S A L)$ during the following $5 \mathrm{~d}$ from bilaterally adrenalectomized mice $(A D X)$ that received saline in their drinking bottles on the 5 consecutive days or $50 \mu \mathrm{g} / \mathrm{ml}$ dexamethasone $(D E X)$ dissolved in saline in their drinking bottles during the 5 consecutive days after surgery. $C$, Hypothalamic samples taken from mice receiving during $5 \mathrm{~d}$ saline $(S A L), 1 \mathrm{mg} / \mathrm{kg}$ haloperidol subcutaneously $(H A L)$, a bilateral orchiectomy treatment $(O R X)$, or a restraint stress treatment $(S T R)$. In all cases mRNA levels are indicated as a relative percentage of endogenous POMC mRNA content normalized to $\beta$-actin content from mice receiving saline. Bars indicate mean \pm SEM of samples of 6-10 mice per group. Statistical analysis was performed by ANOVA followed by a Mann-Whitney $U$ test. ${ }^{*} p<0.05$ versus same mRNA species from saline-treated mice; $* * p 0.01$ versus same mRNA species from saline-treated mice; ${ }^{s} p<0.01$ versus endogenous POMC receiving the same treatment. the $5^{\prime}$ flanking region upstream of the POMC promoter. This distal fragment was not required for the expression of POMC derived in pituitary cells of endocrine origin such as melanotrophs and corticotrophs. Previous studies using transgenic mice demonstrated that cell-specific expression of the POMC gene in the pituitary was controlled by the combinatorial presence of cis-acting elements localized within 300 nucleotides proximal to the transcriptional start site (Liu et al., 1992, 1995). We now show that the neuronal expression of the POMC gene requires additional elements localized further upstream. We cannot rule out the possible participation of DNA sequences present within the introns or the $2 \mathrm{~kb}$ fragment of $3^{\prime}$ flanking sequences that were included in all transgenes studied, although it has been shown that pituitary-specific expression of the POMC gene does not require intronic or 3' flanking sequences (Liu et al., 1992, 1995). Because neurons collectively express a higher number of genes than all other cell types, it is conceivable that cell-specific gene expression in the CNS follows more sophisticated hierarchical mechanisms of transcriptional control that may include additional transcription factors to orchestrate an active enhanceosome (Carey, 1998). There are very few examples in the literature reporting flanking sequences capable of directing the expression of transgenes in a neuron-specific and developmentally regulated manner within the CNS, and they include the vasopressin gene (Ang et al., 1993), the tyrosine hydroxylase gene (Min et al., 1994), and the choline acetyltransferase gene (Lonnerberg et al., 1995).

All independent transgenic pedigrees produced with POMC27* or with $\mathrm{P} 27^{*} 3^{\prime} \Delta$ exhibited a high-level accurate expression in the CNS. This $100 \%$ penetrance suggests that the POMC genomic fragment used in both transgenes has full transcriptional strength to recruit an active enhanceosome, making expression independent from chromosomal influences that could silence transgene expression. Although all transgenic mice generated in this study exhibited a correct spatial expression in the pituitary gland, the levels of expression in corticotrophs of the anterior lobe were always significantly lower than those observed with the endogenous POMC gene. This characteristic has been reported previously for other POMC-derived transgenes (Liu et al., 1992; Rubinstein et al., 1993) and may suggest that a corticotrophic enhacer is localized even further out from the genomic fragments used in this study. Interestingly, pituitary POMCexpressing cells seem to be the only cell lineage that still develops in all null allele mutant mice lacking master genes that control pituitary organogenesis or pituitary differentiation such as Lhx3 (Sheng et al., 1996), Lhx4 (Sheng et al., 1997), Pit-1 (Li et al., 1990), and Prophet-1 (Sornson et al., 1996). The key master gene for pituitary POMC differentiation still remains elusive, although the recently cloned homeodomain transcription factor $\mathrm{Ptx} 1 / \mathrm{P}$ OTX is a possible candidate because it controls POMC expression in the corticotrophic cell line AtT20 (Lamonerie et al., 1996; Szeto et al., 1996).

Tracking POMC expression throughout development showed that the temporal pattern of transgenic ontogeny in the different embryonic areas was identical to that observed for the mouse POMC gene, suggesting that the transgene carries the cis-acting elements required for the early stages of cell lineage determination and phenotype commitment. POMC and POMC27* expression were detected as early as E10.5 in the base of the diencephalon and in the base of the fourth ventricle, preceding all other neuropeptide gene expression in the developing brain. This early expression suggests that POMC peptides may play a developmen- 
tal role in hypothalamic organogenesis or in establishing synaptic pathways to different brain regions. However, this hypothesis has been challenged by the fact that mutant mice lacking $\beta$-endorphin (Rubinstein et al., 1996) or the melanocortin MC-4 receptor (Huszar et al., 1997) did not show any developmental abnormality. The ontogenic analysis performed in this study allowed us to clearly detect POMC gene expression in two CNS regions in which POMC mRNA is not readily observed in the adult rodent, such as the nucleus of the tractus solitarius (Bronstein et al., 1992) and the lumbar spinal cord. Normally, POMC mRNA is not detected in the spinal cord, but under particular traumatic conditions, its expression is rapidly induced (Gutstein et al., 1992; Hughes and Smith, 1993). We observed in sagittal sections taken from E10.5 embryos an intense signal in a region of the neural epithelium that corresponds to the primitive lower spinal cord. POMC expression is also negligible in the adult nucleus tractus solitarii (NTS). Although $\beta$-endorphin containing cell bodies are readily visible in this area, detection of the mRNA has been questionable. We observed, however, a definitive signal in the primitive brainstem at E10.5 and in the developing NTS at E17.5. It still remains unclear why POMC expression in these areas is higher during development than in the adult.

Regulation of arcuate POMC gene expression has been reported in the rat after repetitive inescapable stress by in situ hybridization analysis of coronal sections at different levels of the arcuate nucleus (Baubet et al., 1994). However, in our laboratory we were not able to reproduce those results in the mouse. It is conceivable that in the mouse only a limited subset of hypothalamic POMC neurons is regulated after this treatment and that these differences are masked when we analyze the whole population of hypothalamic POMC mRNA content by an RNase protection assay that used total RNA from single entire hypothalami.

In conclusion, the achievement of an accurate spatial and temporal targeting of transgenes to POMC neurons of the CNS opens the possibility to further explore the physiological function of these neurons and the mechanisms underlying POMC cell fate during organogenesis of the hypothalamus. For example, targeting fluorescent proteins will allow electrophysiological recording of easily identified POMC neurons in whole basal hypothalamic slices. POMC arcuate neurons are also an ideal target to study feeding and fasting physiology and particularly to assess the interplay between leptin and POMC-derived melanocortins, an issue that is now under controversy (Seeley et al., 1997; Boston et al., 1997). Oncogene targeting to these cells in transgenic mice (Alarid et al., 1996) may serve to produce a neuronal cell line with a $\beta$-endorphinergic phenotype useful for studying the properties of this neuron population in vitro and as an invaluable source for transcriptional regulation studies. Finally, we believe that having the capacity to reliably direct transgenes to these cells early in development will contribute to understanding the role of the POMC lineage in hypothalamic organogenesis and lineage commitment for each neuropeptide.

\section{REFERENCES}

Alarid ET, Windle JJ, Whyte DB, Mellon PL (1996) Immortalization of pituitary cells at discrete stages of development by directed oncogenesis in transgenic mice. Development 122:3319-3329.

Ang HL, Carter DA, Murphy D (1993) Neuron-specific expression and physiological regulation of bovine vasopressin transgenes in mice. EMBO J 12:2397-2409.

Baubet V, Fevre-Montange M, Gay N, Debilly G, Bobillier P, Cespuglio R (1994) Effects of an acute immobilization stress upon proopiomel- anocortin (POMC) mRNA levels in the mediobasal hypothalamus: a quantitative in situ hybridization study. Brain Res Mol Brain Res 26:163-168.

Boston BA, Blaydon KM, Varnerin J, Cone RD (1997) Independent and additive effects of central POMC and leptin pathways on murine obesity. Science 278:1641-1644.

Bronstein DM, Schafer MK, Watson SJ, Akil H (1992) Evidence that beta-endorphin is synthesized in cells in the nucleus tractus solitarius: detection of POMC mRNA. Brain Res 587:269-275.

Carey M (1998) The enhanceosome and transcriptional synergy. Cell 92:5-8.

Cheung CC, Clifton DK, Steiner RA (1997) Proopiomelanocortin neurons are direct targets for leptin in the hypothalamus. Endocrinology 138:4489-4492.

Chomczynski P, Sacchi N (1987) Single-step method of RNA isolation by acid guanidinium thiocyanate-phenol-chloroform extraction. Anal Biochem 162:156-159.

Cone RD, Lu D, Koppula S, Vage DI, Klungland H, Boston B, Chen W, Orth DN, Pouton C, Kesterton RA (1996) The melanocortin receptors: agonists, antagonists, and the hormonal control of pigmentation. Recent Prog Horm Res 51:287-317.

Eipper BA, Mains RE (1980) Structure and biosynthesis of proadrenocorticotrophin/endorphin and related peptides. Endocr Rev 1:1-27.

Fan W, Boston BA, Kesterson RA, Hruby VJ, Cone RD (1997) Role of melanocortinergic neurons in feeding and the agouti obesity syndrome. Nature 385:165-168.

Gutstein HB, Bronstein DM, Akil H (1992) Beta-endorphin processing and cellular origins in rat spinal cord. Pain 51:241-247.

Hughes S, Smith ME (1993) Upregulation of the pro-opimelanocortin gene in spinal motoneurons in muscular dystrophy in mice. Neurosci Lett 163:205-207.

Huszar D, Lynch CA, Fairchild-Huntress V, Dunmore JH, Fang Q, Berkemeier LR, Gu W, Kesterson RA, Boston BA, Cone RD, Smith FJ, Campfield LA, Burn P, Lee F (1997) Targeted disruption of the melanocortin-4 receptor results in obesity in mice. Cell 88:131-141.

Japón MA, Rubinstein M, Low MJ (1994) In situ hybridization analysis of anterior pituitary hormone gene expression during fetal mouse development. J Histochem Cytochem 42:1117-1125.

Lamonerie T, Tremblay JJ, Lanctot C, Therrien M, Gauthier Y, Drouin J (1996) Ptx1, a bicoid-related homeo box transcription factor involved in transcription of the pro-opiomelanocortin gene. Genes Dev 10:1284-1295.

Li S, Crenshaw III EB, Rawson EJ, Simmons DM, Swanson LW, Rosenfeld MG (1990) Dwarf locus mutants lacking three pituitary cell types result from mutations in the POU-domain gene pit-1. Nature 347:528-533.

Li SJ, Varga K, Archer P, Hruby VJ, Sharma SD, Kesterson RA, Cone RD, Kunos G (1996) Melanocortin antagonists define two distinct pathways of cardiovascular control by alpha- and gamma-melanocytestimulating hormones. J Neurosci 15:5182-5188.

Liu B, Hammer GD, Rubinstein M, Mortrud M, Low MJ (1992) Identification of DNA elements cooperatively activating proopiomelanocortin gene expression in the pituitary glands of transgenic mice. Mol Cell Biol 12:3978-3990.

Liu B, Mortrud M, Low MJ (1995) DNA elements with AT-rich core sequences direct pituitary cell-specific expression of the proopiomelanocortin gene in transgenic mice. Biochem J 312:827-832.

Lonnerberg P, Lendahl U, Funakoshi H, Arhlund-Richter L, Persson H, Ibanez CF (1995) Regulatory region in choline acetyltransferase gene directs developmental and tissue-specific expression in transgenic mice. Proc Natl Acad Sci USA 92:4046-4050.

Low MJ (1992) The identification of neuropeptide gene regulatory elements in transgenic mice. In: Methods in molecular biology, Vol 13, Protocols in molecular neurobiology (Longstaff A, Revest P, eds), pp 181-204. Totowa, NJ: Humana.

Matera C, Wardlaw SL (1994) Aromatization is not required for androgen induced changes in proopiomelanocortin gene expression in the hypothalamus. Brain Res Mol Brain Res 27:275-280.

Min N, Joh TH, Kim KS, Peng C, Son JH (1994) 5' upstream DNA sequence of the rat tyrosine hydroxylase gene directs high-level and tissue-specific expression to catecholaminergic neurons in the central nervous system of transgenic mice. Brain Res Mol Brain Res 27:281-289.

Olson GA, Olson RD, Kastin AJ (1997) Endogenous opiates: 1996. Peptides 18:1651-1688. 
Rubinstein M, Mortrud M, Low MJ (1993) Rat and mouse proopiomelanocortin gene sequences target tissue-specific expression to the pituitary gland but not to the hypothalamus of transgenic mice. Neuroendocrinology 58:373-380.

Rubinstein M, Mogil JS, Japón MA, Chan EC, Allen RG, Low MJ (1996) Absence of opioid stress-induced analgesia in mice lacking $\beta$-endorphin by targeted mutagenesis. Proc Natl Acad Sci USA 93:3995-4000.

Seeley RJ, Yagaloff KA, Fisher SL, Burn P, Thiele TE, van Dijk G, Baskin DG, Schwartz MW (1997) Melanocortin receptors in leptin effects. Nature 390:349.

Seifer DB, Collins RL (1990) Current concepts of beta-endorphin physiology in female reproductive dysfunction. Fertil Steril 54:757-771.

Sheng HZ, Zhadanov AB, Mosinger Jr B, Fujii T, Bertuzzi S, Grinberg A, Lee EJ, Huang SP, Mahon KA, Westphal H (1996) Specification of pituitary cell lineages by the LIM homeobox gene Lhx3. Science 272:1004-1007.

Sheng HZ, Moriyama K, Yamashita T, Li H, Potter SS, Mahon KA,
Westphal H (1997) Multistep control of pituitary organogenesis. Science 278:1809-1812.

Smith AI, Funder JW (1988) Proopiomelanocortin processing in the pituitary, central nervous system, and peripheral tissues. Endocr Rev 9:159-179.

Sornson MW, Wu W, Dasen JS, Flynn SE, Norman DJ, O'Connell SM, Gukovsky I, Carriere C, Ryan AK, Miller AP, Zuo L, Gleiberman AS, Andersen B, Beamer WG, Rosenfeld MG (1996) Pituitary lineage determination by the Prophet of Pit-1 homeodomain factor defective in Ames dwarfism. Nature 384:327-333.

Szeto DP, Ryan AK, O'Connell SM, Rosenfeld MG (1996) P-OTX: a PIT-1-interacting homeodomain factor expressed during anterior pituitary gland development. Proc Natl Acad Sci USA 93:7706-7710.

Treier M, Rosenfeld MG (1996) Hypothalamic-pituitary axis: codevelopment of two organs. Curr Opin Cell Biol 8:833-843.

Yang Z, Lim AT (1995) Progesterone, but not estrogen, modulates the cAMP system mediated ir-beta-endorphin secretion and POMC mRNA expression from rat hypothalamic cells in culture. Brain Res 678:251-258. 